\title{
Non3 is an essential Drosophila gene required for proper nucleolus assembly
}

\author{
E.N. Andreyeva ${ }^{1} \otimes$, A.A. Ogienko ${ }^{1,2}$, A.A. Yushkova ${ }^{1,2}$, J.V. Popova ${ }^{1,3}$, G.A. Pavlova ${ }^{1}$, E.N. Kozhevnikova ${ }^{1,3}$, \\ A.V. Ivankin ${ }^{1}$, M. Gatti ${ }^{1,4}$, A.V. Pindyurin ${ }^{1,2,3}$ 龱 \\ ${ }^{1}$ Institute of Molecular and Cellular Biology, SB RAS, Novosibirsk, Russia \\ ${ }^{2}$ Novosibirsk State University, Novosibirsk, Russia \\ ${ }^{3}$ Institute of Cytology and Genetics, SB RAS, Novosibirsk, Russia \\ ${ }^{4}$ IBPM CNR and Department of Biology and Biotechnology, Sapienza University of Rome, Rome, Italy \\ 凶e-mail: andreeva@mcb.nsc.ru; a.pindyurin@mcb.nsc.ru
}

The nucleolus is a dynamic non-membrane-bound nuclear organelle, which plays key roles not only in ribosome biogenesis but also in many other cellular processes. Consistent with its multiple functions, the nucleolus has been implicated in many human diseases, including cancer and degenerative pathologies of the nervous system and heart. Here, we report the characterization of the Drosophila Non3 (Novel nucleolar protein 3) gene, which encodes a protein homologous to the human Brix domain-containing Rpf2 that has been shown to control ribosomal RNA (rRNA) processing. We used imprecise $P$-element excision to generate four new mutant alleles in the Non3 gene. Complementation and phenotypic analyses showed that these Non3 mutations can be arranged in an allelic series that includes both viable and lethal alleles. The strongest lethal allele $\left(\mathrm{Non}^{\Delta 600}\right)$ is a genetically null allele that carries a large deletion of the gene and exhibits early lethality when homozygous. Flies heterozygous for Non $3^{\Delta 600}$ occasionally exhibit a mild reduction in the bristle size, but develop normally and are fertile. However, heteroallelic combinations of viable Non 3 mutations (Non $3^{197}$, Non $3^{310}$ and Non $3^{259}$ ) display a Minute-like phenotype, consisting in delayed development and short and thin bristles, suggesting that they are defective in ribosome biogenesis. We also demonstrate that the Non3 protein localizes to the nucleolus of larval brain cells and it is required for proper nucleolar localization of Fibrillarin, a protein important for post-translational modification and processing of rRNAs. In summary, we generated a number of genetic and biochemical tools that were exploited for an initial characterization of Non3, and will be instrumental for future functional studies on this gene and its protein product. Key words: Drosophila melanogaster; nucleolus; Minute-like phenotype; Non3; Fibrillarin; Rpf2; Brix domain; ribosome biogenesis.

For citation: Andreyeva E.N., Ogienko A.A., Yushkova A.A., Popova J.V., Pavlova G.A., Kozhevnikova E.N., Ivankin A.V., Gatti M., Pindyurin A.V. Non3 is an essential Drosophila gene required for proper nucleolus assembly. Vavilovskii Zhurnal Genetiki i Selektsii = Vavilov Journal of Genetics and Breeding. 2019;23(2):190-198. DOI 10.18699/VJ19.481

\section{Ген Non3 необходим для формирования ядрышка у Drosophila}

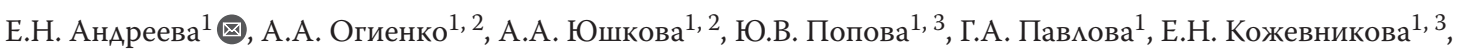 \\ А.В. Иванкин ${ }^{1}$, М. Гатти ${ }^{1,4}$, А.В. Пиндюрин ${ }^{1,2,3}$ 圂 \\ ${ }^{1}$ Институт молекулярной и клеточной биологии Сибирского отделения Российской академии наук, Новосибирск, Россия \\ ${ }^{2}$ Новосибирский национальный исследовательский государственный университет, Новосибирск, Россия \\ ${ }^{3}$ Федеральный исследовательский центр Институт цитологии и генетики Сибирского отделения Российской академии наук, \\ Новосибирск, Россия \\ ${ }^{4}$ Институт молекулярной биологии и патологии Национального исследовательского совета и Отделение биологии и биотехнологии, \\ Римский университет Ла Сапиенса, Рим, Италия \\ 凶e-mail:andreeva@mcb.nsc.ru; a.pindyurin@mcb.nsc.ru
}

Ядрышко представляет собой динамичную немембранную внутриядерную органеллу, которая играет ключевую роль как в биогенезе рибосом, так и в других клеточных процессах. Нарушение функции ядрышка ассоциировано со многими заболеваниями человека, в том числе с дегенеративными патологиями нервной и сердечно-сосудистой систем, а также с образованием злокачественных опухолей. В данной работе нами впервые охарактеризована функция гена Non3 (Novel nucleolar protein 3) у плодовой мушки Drosophila melanogaster, который кодирует гомолог Brix домен-содержащего белка человека Rpf2, участвующего в процессе созревания рибосомной РНК (рРНК). С помощью метода неточной эксцизии Р-элемента мы получили набор из четырех мутаций по гену Non3. Эти мутации формируют аллельный ряд, который включает в себя как жизнеспособные, так и летальные аллели. Non3 $3^{\Delta 600}$ - это нуль-аллель, который несет делецию большей части гена и является ранней рецессивной леталью. Мухи генотипа Non3 $3^{\Delta 600} /+$ демонстрируют очень слабое уменьшение длины и толщины торакальных щетинок, но при этом развиваются нормально и фертильны. Гетероаллельные комбинации жизнеспособных мутаций гена Non3 $\left(\right.$ Non3 $^{197}$, Non3 $3^{310}$ и Non $\left.3^{259}\right)$ имеют укоро- 


\begin{abstract}
ченные и тонкие торакальные щетинки, также у них наблюдается некоторое замедление онтогенеза. Такой же паттерн нарушений был ранее описан в литературе как Minute-like фенотип, который характерен при дефектах биогенеза рибосом. Кроме того, мы обнаружили, что белок Non3 является компонентом ядрышка в клетках вентрально-мозгового ганглия личинок третьего возраста и необходим для локализации белка Fibrillarin, важного для пост-трансляционной модификации и процессинга рРНК, в этом немембранном внутриядерном субкомпартменте. Полученный нами набор генетических и биохимических инструментов, использованных в ходе данной работы для первичной характеристики гена Non3, будет полезен также для исследований функции этого гена и его белкового продукта в будущем.

Ключевые слова: Drosophila melanogaster; ядрышко; фенотип Minute-like; Non3; Fibrillarin; Rpf2; Brix домен; биогенез рибосом.
\end{abstract}

\section{Introduction}

Ribosomes are highly conserved macromolecular machines that organize and catalyze mRNA translation in all organisms. In higher eukaryotes, mature cytoplasmic ribosomes include 4 ribosomal RNA molecules (rRNAs; $18 \mathrm{~S}, 25 \mathrm{~S} / 28 \mathrm{~S}, 5.8 \mathrm{~S}$ and 5S) and 79 ribosomal proteins (RPs) (Marygold et al., 2007; Xue, Barna, 2012; Genuth, Barna, 2018). Drosophila melanogaster has a 2S rRNA instead of 5S rRNA (Stage, Eickbush, 2007). Coordinated processing of $45 \mathrm{~S} / 47 \mathrm{~S}$ precursor rRNA (pre-rRNA) into the mature $18 \mathrm{~S}, 5.8 \mathrm{~S}$ and $25 \mathrm{~S} / 28 \mathrm{~S}$ rRNAs is a central process in the highly orchestrated ribosome assembly (Henras et al., 2015). Ribosomal biosynthesis includes progressive association of individual ribosomal proteins with maturating rRNAs, export of pre-ribosome particles from the nucleolus to the cytoplasm and their assembly into mature ribosomes. More than 200 different factors are required for ribosome biosynthesis and quality control of ribosome maturation on the path from the nucleolus to the cytoplasm (Kressler et al., 2017).

Depletion of eukaryotic RPs could be associated with disturbances in pre-rRNA processing and nucleolar organization (Neumüller et al., 2013; Farley-Barnes et al., 2018). In Drosophila, mutations in $75 \%$ of the genes encoding protein components of mature cytoplasmic ribosomes dominantly cause a Minute phenotype. The Minute syndrome includes short and thin bristles, delayed development, and reduced viability and fertility (Marygold et al., 2007). In addition, decreased levels of some Drosophila RPs result in overgrowth of specific tissues and melanotic tumors (Goudarzi, Lindström, 2016). Mutations in genes encoding RPs and ribosome biogenesis factors lead to a series of congenital human disorders collectively called ribosomopathies, and predispose to cancer (Narla, Ebert, 2010; Henras et al., 2015; Mills, Green, 2017; Núñez Villacís et al., 2018). In some cases, these diseases are also caused by haploinsufficiency for these genes caused by somatic mutations (Narla, Ebert, 2010; Núñez Villacís et al., 2018).

Although ribosomes have been considered for many years as ancient and rather invariable molecular machines, several lines of evidence indicate that they are instead heterogeneous in both RPs and rRNA composition (Genuth, Barna, 2018). Indeed, mutations in RP coding genes lead to tissue-specific pleiotropic phenotypes in multicellular organisms (Kongsuwan et al., 1985; Draptchinskaia et al., 1999; Marygold et al., 2005; Gupta, Warner, 2014; Shi, Barna, 2015). Pleiotropic phenotypes could be only partially explained by the fact that several of these genes have paralogues (Xue, Barna, 2012). For example, in humans there are three paralogous RP genes (RPS4X, RPS4Y1 and RPSY2) encoding the RPS4 protein, and one of them (RPSY2) is specifically expressed in testis and prostate (Fisher et al., 1990; Lopes et al., 2010). In Drosophila, a total of 88 genes encoding 79 different RPs have been identified; nine of these genes are present as duplicates (Marygold et al., 2007). These duplicated genes are expressed at different levels, and in some cases with a tissue-specific pattern. For instance, RpL22L, RpS5b, RpS19a, RpL10Aa and $R p L 37 b$ exhibit enhanced expression in the testes compared to their paralogues, suggesting specific composition of testis ribosomes (Marygold et al., 2007; Kearse et al., 2011).

A complex sequence of processing steps, involving several protein factors, is required to gradually release the mature rRNAs from precursor pre-rRNA (Henras et al., 2015). Many of these factors contain putative RNA-binding domains (e. g., GAR, RRM, KH, Brix, S1, dsRBD, and Zinc finger) and/or protein-protein interaction domains (WD40, HEAT, TPR, and HAT), but the enzymatic activities of most proteins required for ribosome biosynthesis have not been determined (Henras et al., 2015). One of the Brix domain-containing proteins is the Saccharomyces cerevisiae ribosome assembly factor Rpf2 (Ribosome production factor 2), which in complex with Rrs1 plays a role in the early steps of the 60S ribosome subunit maturation (Zhang et al., 2007; Henras et al., 2015; Kressler et al., 2017). Rpf2 binds the Rpl5 and Rpl11 ribosomal proteins and the Rrs1 protein, forming both the $5 \mathrm{~S}$ ribonucleoprotein particle necessary for $25 \mathrm{~S}$ rRNA maturation and the large $60 \mathrm{~S}$ ribosomal subunit (Tutuncuoglu et al., 2016). Depletion of Rpf2 results in defects in pre-rRNA processing (Wehner, Baserga, 2002).

The Rpf2 proteins are highly conserved. The Drosophila Rpf2 orthologous protein is encoded by the Novel nucleolar protein 3 (Non3) gene (CG7993). Non3, which contains a Brix domain, exhibits $66 \%$ similarity and $47 \%$ sequence identity with human Rpf2 (Gramates et al., 2017). Thus far, most studies on Non3 were carried in tissue culture cells. Most interestingly, an RNAi-based screen showed that Non3 depletion results in short mitotic spindles. In addition, it has been shown that in interphase cells the GFP-tagged Non3 protein localizes to the nucleolus (Moutinho-Pereira et al., 2013). These phenotypes, and the finding that RNAi-mediated depletion of other nucleolar proteins results in short spindles, suggest that the short-spindle phenotype observed in Non3 RNAi cells is due to limited translation of tubulin and/or other spindle components. However, it is also possible that Non3 has a direct role in spindle formation (Moutinho-Pereira et al., 2013).

To address the mitotic role of Non3, and to provide a Drosophila model for the study of the Rpf2 function in nucleolus assembly and ribosome maturation, we characterized the Non 3 gene. We generated several allelic mutations in the gene and 
showed that these mutations affect viability, fertility and bristle formation, resulting in a Minute-like phenotype. We also show that Non3 localizes to the nucleolus and is required for proper formation of this organelle. We believe that the mutations and the reagents generated in this study will be instrumental to define the role of Non3 in living flies.

\section{Materials and methods}

Fly stocks. Flies were raised and crossed on standard cornmeal agar media at $25^{\circ} \mathrm{C}$. The fly stocks used in this study are from the Bloomington Stock Center (Bloomington, IN, USA; flystocks.bio.indiana.edu): \#30094 ( $w^{1118} ; \mathrm{P}\left\{w^{+m C}=\mathrm{EP}\right\}$

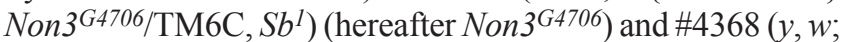
$\left.K i, \mathrm{P}\left\{r y^{+}, \Delta 2-3\right\} 99 \mathrm{~B}\right)($ hereafter $\Delta 2-3)$. The $y^{l}, \mathrm{P}\left\{y^{+t 7.7}=\right.$ nosphiC31 \int.NLS $\}$ X; P $\left\{y^{+t 7.7}=\right.$ CaryP $\}$ attP40 fly line was kindly provided by Sergei A. Demakov (Institute of Molecular and Cellular Biology of the Siberian Branch of the Russian Academy of Sciences, Novosibirsk, Russia).

Generation of new Non3 alleles. The Non 3 mutants were generated by imprecise excision (O'Brochta et al., 1991) of the $\mathrm{P}\{\mathrm{EP}\}$ transposon located $48 \mathrm{bp}$ downstream of the predicted transcription start site of Non3 in the Non3 $3^{G 4706}$ line (Fig. 1). The $\Delta 2-3$ strain was used as a source of transposase (Robertson et al., 1988), and the $\mathrm{F}_{1}$ progeny of Non3 $3^{G 4706 / \Delta 2-3}$ flies was screened for loss of the mini-white $\left(w^{+m C}\right)$ marker carried by the $\mathrm{P}\{\mathrm{EP}\}$ transposon. 512 independent excision lines were established and analyzed by PCR using primers Ins-non3-F2 (5'-CGGTTGTTTTCACATCCCTAAC-3') and Ins-non3-R (5'-CGTCTGTGCTAATGTTCTTCTTCTTG-3') (primer positions are shown in Fig. 1). We identified one line with a large deletion internal to the Non3 gene, three lines with remnants of the $\mathrm{P}\{\mathrm{EP}\}$ transposon, and several lines in which the transposon was most probably precisely excised. Only one of the latter lines was further analyzed and confirmed to be generated by precise excision of the $\mathrm{P}\{\mathrm{EP}\}$ transposon; it was designated as Non $3^{e x}$. The PCR products obtained from all new Non 3 mutant lines were cloned in a plasmid vector and sequenced (Suppl. Fig. 1) $)^{1}$.

Construction of rescue plasmid and germ-line transformation. To make a rescue construct, we cloned a $2.76-\mathrm{kb}$ genomic DNA fragment [chr3R:18222722-18225482; the coordinates are from Release 6 of the Drosophila melanogaster genome assembly (Hoskins et al., 2015)] carrying the Non3 gene into the pUASTattB vector (Bischof et al., 2007) by substituting a UAS promoter, a multiple cloning site and a SV40 terminator. Details of plasmid construction are available upon request. The cloned genomic DNA fragment contains 27 known single nucleotide polymorphisms (SNPs) (Mackay et al., 2012; Huang et al., 2014) (Suppl. Fig. 2). The rescue construct was injected at the concentration of $300 \mathrm{ng} / \mu \mathrm{l}$ into embryos carrying attP40 landing site (Markstein et al., 2008) and expressing the phiC31 integrase in the germline (Bischof et al., 2007).

Anti-Non3 antibody production. The full-length Non3 coding sequence (corresponding to nucleotides 98-1060 of GenBank accession no. NM_142437.3, but with the synonymous nucleotide substitution $1000 \mathrm{~T}>\mathrm{A}$ ) was PCR-amplified from 0-24 h Drosophila wild-type (Canton-S) embryonic

\footnotetext{
${ }^{1}$ Supplementary Figures 1, 2 are available in the online version of the paper:
} http://www.bionet.nsc.ru/vogis/download/pict-2019-23/appx3.pdf
cDNA library. The amplified DNA fragment was cloned inframe into the pGEX-4T-1 plasmid vector (GE Healthcare) downstream of the glutathione S-transferase (GST) coding sequence to produce pGEX-4T-Non3 construct. Details of plasmid construction are available upon request. The GSTNon3 fusion protein was expressed in Escherichia coli and subsequently purified as described previously (Chalkley, Verrijzer, 2004). The purified protein was used to immunize mice. Polyclonal antibodies were affinity purified from serum as previously described (Chalkley, Verrijzer, 2004).

Double-stranded RNA (dsRNA) production. A 730-bp fragment of the Non3 coding sequence was PCR-amplified with primers CG7993-rnaF1 (5'-TAATACGACTCACTAT AGGGAGGTGTTGCTGGCCAG-3') and CG7993-rnaR1 (5'-TAATACGACTCACTATAGGGAGGGCGTCTGTGCT AATG-3') (underlined is the added T7 promoter sequence) from the pGEX-4T-Non3 plasmid. The purified PCR product was used as a template to synthesize dsRNA as described earlier (Somma et al., 2002), with the minor modifications: the phenol/chloroform extraction step was omitted and DNaseI treatment was performed at the end of the procedure.

S2 cell culture and RNA interference (RNAi). S2 cells (for details, see Strunov et al., 2016) were cultured at $25^{\circ} \mathrm{C}$ in $39.4 \mathrm{~g} / \mathrm{L}$ Shields and Sang M3 Insect medium (Sigma, S8398) supplemented with $0.5 \mathrm{~g} / \mathrm{L} \mathrm{KHCO}_{3}$ and $20 \%$ heat-inactivated fetal bovine serum (FBS) (Thermo Scientific, 10270106). RNAi treatments were carried out as described previously (Somma et al., 2008), with the following modifications: $25 \mu \mathrm{g}$ of dsRNA was added to the cells three times (on the first, the third and the fifth day of incubation), and cells were harvested for analyses after 7 days of RNAi.

Reverse transcription followed by quantitative PCR (RT-qPCR). RNAi efficiency in S2 cells was assessed by RT-qPCR. Total RNA was isolated from control and dsRNAtreated cells using RNAzol ${ }^{\circledR}$ RT reagent (Molecular Research Center, RN 190); genomic DNA was eliminated using the RapidOut DNA Removal Kit (Thermo Fisher Scientific, K2981) according to the manufacturer's instructions. Synthesis of cDNA and qPCR were performed as described previously (Ogienko et al., 2018), using the following gene-specific primers: RTNon3-Fw2 (5'-CGCTTTTACGCATCAGGAAACC-3') and RT-Non3-Rev2 (5'-CTTCCTTCCGTCCAAAAACAGC-3') for Non3 (this study), and RPL32-realtime-F (5'-CTAAG CTGTCGCACAAATGG-3') and RPL32-realtime-R (5'-AG GAACTTCTTGAATCCGGTG-3') for $R p L 32$ (Yang et al., 2013), which was used as a reference gene.

Western blotting. S2 cells were harvested by centrifugation at $200 \mathrm{~g}$ for $5 \mathrm{~min}$ at room temperature, washed with phosphate-buffered saline (PBS) and centrifuged again. Pellets were lysed in RIPA buffer (Sigma, R0278) containing $1 \times$ Halt $^{\mathrm{TM}}$ Protease and Phosphatase Inhibitor Cocktail (Thermo Fisher Scientific, 1861282), and the lysates were clarified by centrifugation at $15.000 \mathrm{~g}$ for $15 \mathrm{~min}$ at $4{ }^{\circ} \mathrm{C}$. The samples were normalized to the total amount of protein using DC Protein Assay (Bio-Rad, 5000116). Each normalized sample was mixed with an equal volume of $2 \times$ Laemmli buffer and incubated at $95^{\circ} \mathrm{C}$ for $5 \mathrm{~min}$ prior to loading on a SDS-PAGE gel. Larval tissues were dissected, homogenized in $1 \times$ Laemmli buffer with a pestle and incubated at $95{ }^{\circ} \mathrm{C}$ for $5 \mathrm{~min}$ prior to loading on a SDS-PAGE gel. The following primary 


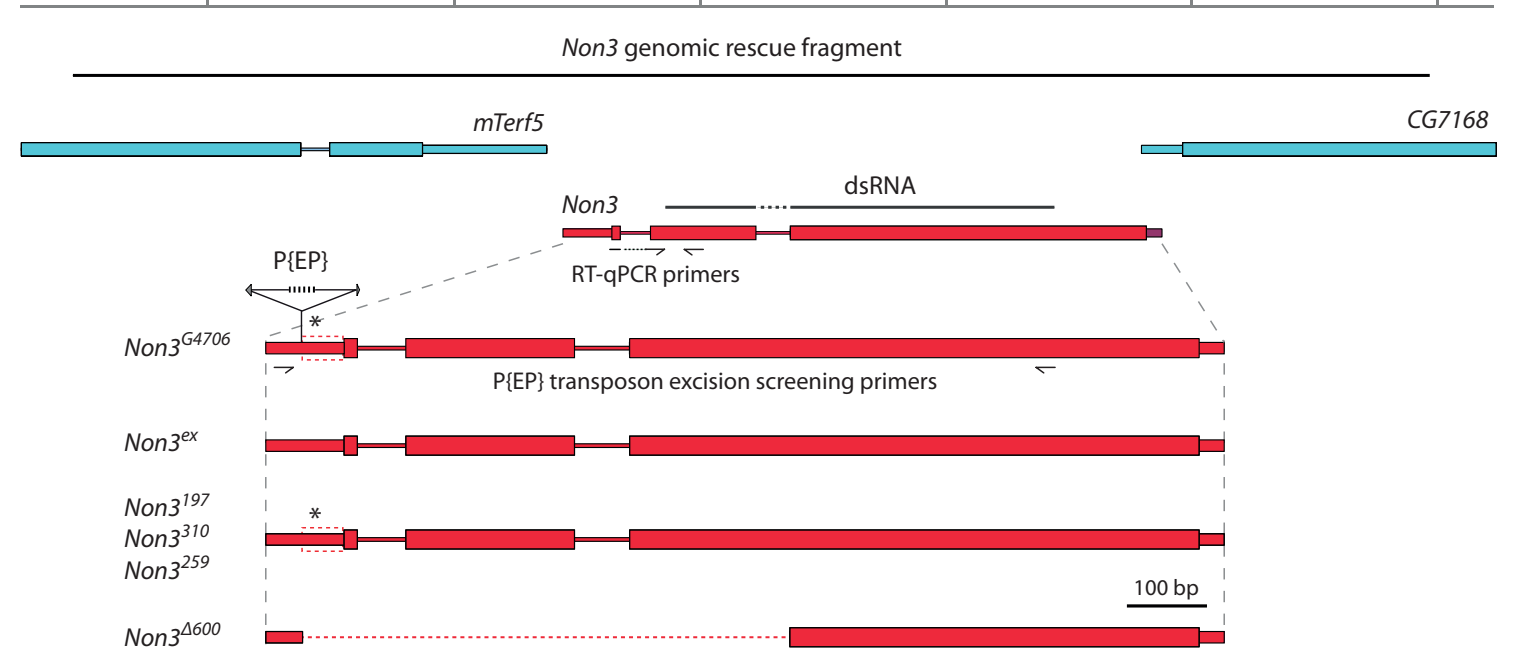

Fig. 1. Schematic representation of the genomic locus containing Non3 and its flanking genes.

The Non 3 gene, which is on the forward strand, is shown in red. The mTerf5 and CG7168 genes, which are on the reverse strand, are shown in light blue. Coding sequences, UTRs and introns are represented by wide bars, narrow bars and lines, respectively. The Non3G4706 mutation is caused by an insertion of the P\{EP\} transposon (which is not shown to scale) 48 bp downstream of the predicted transcription start of the gene. Non $3^{\Delta 600}$ is a 617-bp deletion removing the region (indicated by a dotted line) downstream from the P\{EP\} insertion site. Non3 ${ }^{197}$, Non $3^{310}$ and Non $3^{259}$ are hypomorphic mutations carrying remnants of $P$-element ends, which were generated by imprecise excision of the $\mathrm{P}\{\mathrm{EP}\}$ transposon. Non3 ${ }^{\text {ex }}$ has been generated by a precise excision of the $\mathrm{P}\{\mathrm{EP}\}$ transposon without any disruption of the gene. The arrows indicate the position of primer pairs used for identification and characterization of the mutations. The alternative coding sequence in the Non $3^{\mathrm{G} 4706}$, Non $3^{197}$, Non $3^{310}$ and Non $3^{259}$ alleles, which is likely to start from an ATG codon located within the $5^{\prime}$ P-element remnants, is delimited by dotted rectangles and marked with asterisks (for additional details see Suppl. Fig.1). The DNA segments used for the rescue construct and for the dsRNA synthesis are shown above the Non3 gene.

antibodies were used: mouse anti-Lamin Dm0 (1:300; DSHB, ADL67.10), mouse anti- $\alpha$-Tubulin (1:5000; Sigma, T6199), mouse anti- $\beta$-Tubulin $[1: 800$; BX69 (Tavares et al., 1996), kindly provided by Harald Saumweber (Humboldt University Berlin, Institute of Biology, Berlin, Germany)] and mouse anti-Non3 (1:5000; this study). The primary antibodies were detected with HRP-conjugated goat $\alpha$-mouse $\operatorname{IgG}$ (1:3.500; Life Technology, G-21040) and images were captured using an Amersham Imager 600 System (GE Healthcare).

Immunofluorescence (IF) staining. Brains from late third instar larvae were dissected and immunostained as described earlier (Bonaccorsi et al., 2000). The following primary antibodies were used: mouse anti-Non3 (1:250; this study) and rabbit anti-Fibrillarin (1:300; Abcam, ab5821). They were detected with goat anti-mouse IgG conjugated to Alexa Fluor 488 (1:500; Invitrogen, A-11001) and goat antirabbit IgG conjugated to Alexa Fluor 568 (1:350; Invitrogen, A-11036), respectively. DAPI was used to stain DNA. IF images were acquired with a Zeiss Axio Imager M2 fluorescence microscope equipped with an Axiocam 506 mono (D) camera and a NeoFluar 100× /1.3 Oil objective using the ZEN 2012 software.

\section{Results and discussion}

\section{Generation and characterization of the novel Non3 mutations}

D. melanogaster Non3 gene (CG7993) maps to the 90F8 region of polytene chromosomes, includes two small introns, and has a total size of $1221 \mathrm{bp}$. It is ubiquitously expressed, with the highest expression levels in embryos (0-12 h), nervous ganglia, ovaries and testes (Gramates et al., 2017). When we began this work, only a $P$-element-induced mutation in the Non 3 gene (Non3 ${ }^{G 4706}$ ) was available. Animals homozygous for this mutation are lethal and die at the late pupal stages. We sequenced Non $3^{G 4706}$ and confirmed that this mutation carries a $\mathrm{P}\{\mathrm{EP}\}$ transposon inserted $48 \mathrm{bp}$ downstream of the predicted transcription start of the gene (see Fig. 1, Suppl. Fig. 1). We then used imprecise $P$-element excision to generate a set of additional mutations in Non3. We isolated three hypomorphic alleles (Non $3^{197}$, Non $3^{310}$ and Non $3^{259}$ ) and one putative null allele $\left(N o n 3^{\triangle 600}\right)$ (see Material and Methods for details). As a control, we also generated a chromosome bearing a precise excision of the $\mathrm{P}\{\mathrm{EP}\}$ transposon (Non $3^{\text {ex }}$ ).

Flies homozygous for Non $3^{\text {ex }}$ are fully viable and fertile, excluding a possible influence of background mutations on the "starting" chromosome (see Fig. 1). All mutations generated by imprecise excision were sequenced and their precise locations and molecular structures are shown in Figure 1 and Suppl. Fig. 1. The Non $3^{\Delta 600}$ allele carries a deletion of $617 \mathrm{bp}$ of the Non 3 coding region and contains 13 residual bp of $3^{\prime}$ end of the $P$-element. The Non $3^{197}$, Non $3^{310}$ and Non $3^{259}$ mutations carry differently sized remnants of the $5^{\prime}$ and $3^{\prime}$ $P$-element ends (373, 367 and $453 \mathrm{bp}$, respectively) that do not disrupt the coding region of the gene. Non $3^{\text {ex }}$ did not show any sequence variation compared to wild type.

\section{Non3 mutants exhibit a Minute-like phenotype}

We next performed a phenotypic analysis and a functional categorization of the new mutations. This investigation was possible because the "starting" Non $3^{G 4706}$ chromosome does not carry background mutations, as shown by the charac- 
Complementation analysis of Non3 mutant alleles

\begin{tabular}{|c|c|c|c|c|c|c|}
\hline o $\quad$ + & Non3 $3^{e x}$ & Non3 ${ }^{197}$ & Non3 310 & Non3 $3^{259}$ & Non3 $3^{G 4706}$ & $N_{o n 3}{ }^{\Delta 600}$ \\
\hline Non3 $3^{e x}$ & $V, F, N B$ & $\mathrm{~V}, \mathrm{~F}, \mathrm{NB}$ & $V, F, N B$ & $V, F, N B$ & $V, F, N B$ & $V, F, N B$ \\
\hline Non3 $3^{197}$ & & $V, F, d b$ & $V, F, d b$ & $V, F, d b$ & $\mathrm{~V}, \mathrm{ss}, \mathrm{DB}$ & PLE, S, DB \\
\hline Non $3^{310}$ & & & $V, F, d b$ & $V, F, d b$ & $\mathrm{~V}, \mathrm{ss}, \mathrm{DB}$ & $\mathrm{PL}$ \\
\hline Non3 $3^{259}$ & & & & $\mathrm{~V}, \mathrm{ss}, \mathrm{db}$ & $\mathrm{V}, \mathrm{S}, \mathrm{DB}$ & $\mathrm{PL}$ \\
\hline Non3 $3^{G 4706}$ & & & & & $\mathrm{PL}$ & $\mathrm{PL}$ \\
\hline Non $3^{\Delta 600}$ & & & & & & $\mathrm{EL}$ \\
\hline
\end{tabular}

Note: $V$, viable both sexes; $F$, fertile both sexes; EL, early lethal (L1/L2); PL, pupal lethal; PLE, pupal lethal with escapers; $S$, sterile in both sexes; ss, semi sterile; $\mathrm{NB}$, normal bristles; $\mathrm{DB}$, defective bristles; db, slightly defective bristles.

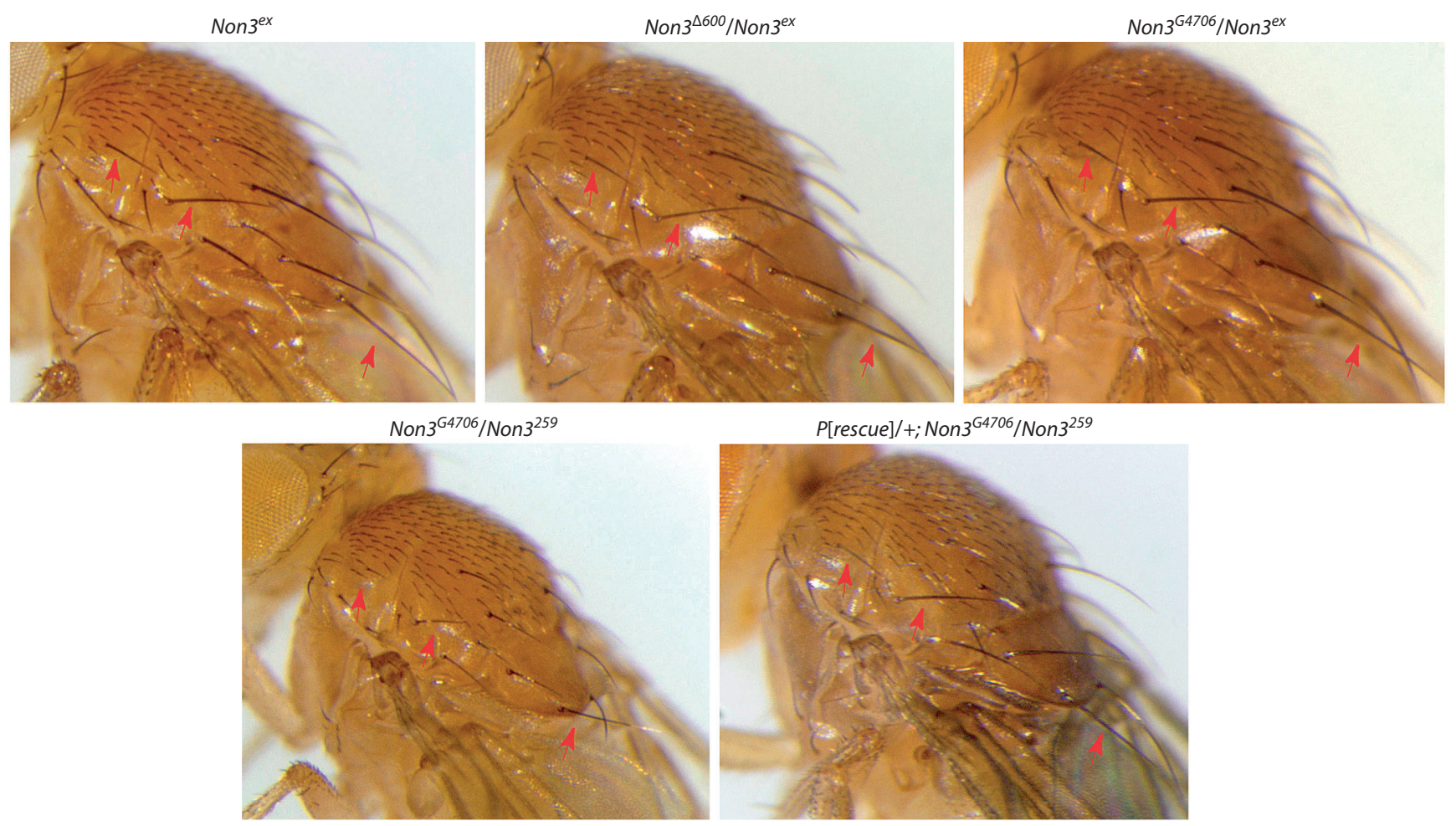

Fig. 2. Non3 mutants exhibit a recessive Minute-like bristle phenotype.

Non3 ${ }^{64706 / N o n} 3^{259}$ flies have shorter and thinner bristles than Non3 ${ }^{e x}$ used as control. This is most clearly seen by comparing the notum bristles (red arrows). Non3 $3^{4600 / N o n} 3^{e x}$ and Non364706/Non3ex flies exhibit a very weak dominant bristle phenotype. Addition of a wild-type copy of Non3 (P[rescue]) to Non364706/ Non $3^{259}$ flies leads to a complete rescue of the Minute-like phenotype.

terization of $N o n 3^{e x}$ precise excision line. We performed a complementation analysis between all extant Non3 alleles, including Non $3^{G 4706}$ (see the Table). This analysis showed that the Non $3^{\Delta 600}$ allele is a homozygous larval lethal that dies at the first instar larval (L1) stage, a finding that suggests that Non $3^{\Delta 600}$ is a genetically null mutation. The Non $3^{G 4706}$ homozygotes and the Non $3^{\Delta 600 / N o n} 3^{G 4706}$ heterozygotes are also lethal but die during pupal development. All the remaining Non3 mutations (Non3 $3^{197}, N_{N o n} 3^{310}$ and Non $3^{259}$ ) are homozygous viable. However, Non $3^{\Delta 600 / N o n} 3^{259}$ and Non $3^{\Delta 600 /}$ Non $3^{310}$ heterozygotes are mostly pupal lethal. Non $3^{\Delta 600 /}$ Non $3^{197}$ also exhibit pupal lethality but produce some escapers with reduced fertility. In addition, viable mutant combinations bearing the $\mathrm{Non}^{310}$ allele are more fertile than those carrying $N o n 3^{259}$. These results suggest that the Non 3 mutations can be ordered in an allelic series with $N o n 3^{\Delta 600}>N o n 3^{G 4706}>$ Non $3^{259}>$ Non $3^{310}>$ Non $3^{197}$.

In Drosophila, mutations in $75 \%$ of the RP coding genes dominantly produce a Minute phenotype characterized by prolonged development, short and thin bristles, and reduced viability and fertility, often accompanied by additional patterning and growth defects such as roughened eyes, abnormal wings, defective abdominal segmentation, and small body size (Marygold et al., 2005). Bristle production and gametogenesis require maximal protein synthesis and are therefore particularly sensitive to a reduction in the translational capacity of 


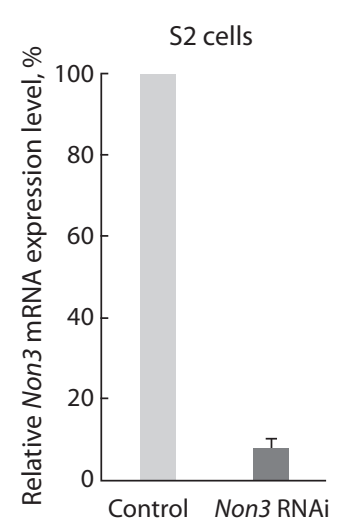

$b$

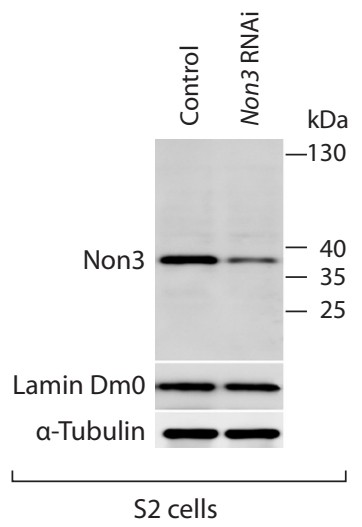

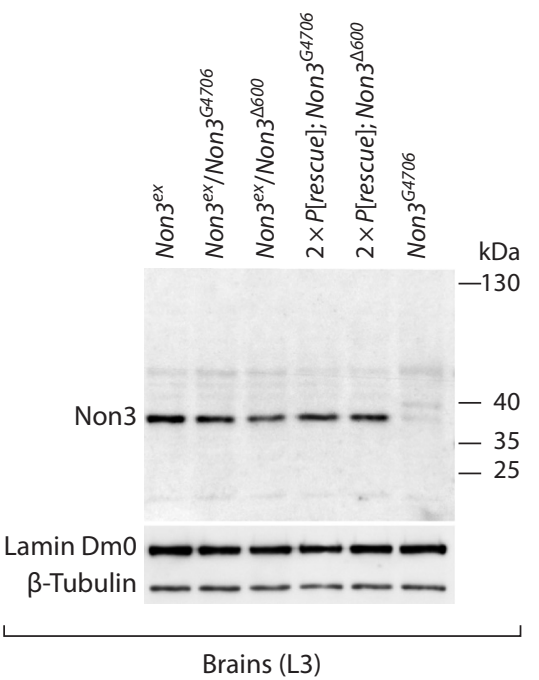

$d$

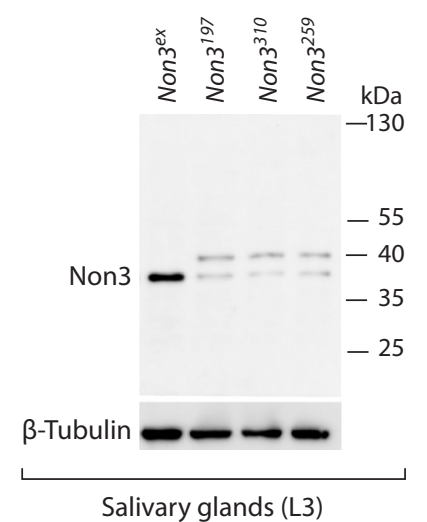

Fig. 3. Expression of the Non3 protein in S2 cells and in larval tissues from Non3 mutants.

(a) RT-qPCR showing that in Non3 RNAi S2 cells the target mRNA level is strongly reduced compared to control cells. Each bar represents the average of three separate biological replicates (RNA isolations); error bar, standard error of the mean (SEM). (b) Western blot of S2 cell extracts showing that the anti-Non3 antibody specifically recognizes one band of the predicted size ( $\sim 37 \mathrm{kDa})$, which is substantially reduced in Non3 RNAi cells. Lamin Dm0 and a-Tubulin are loading controls. (c) Western blot from larval brain extracts showing a clear Non3 band in all samples expressing a wild-type (Non $3^{\text {ex }}$ ) copy of the Non3 gene; this band is strongly reduced in Non $3^{\mathrm{G} 4706}$ homozygous mutants. Lamin Dm0 and $\beta$-Tubulin are loading controls. Non $3^{\Delta 600}$ homozygotes could not be analyzed because they are early lethals. $(d)$ Western blot from larval salivary gland extracts showing that in Non $3^{259}$, Non $3^{310}$ and Non3 ${ }^{197}$ homozygous mutants the level of the wild-type Non3 protein is substantially reduced. In addition, these mutants exhibit aberrant proteins of 39-40 kDa, which are probably transcribed from the ATG codons located within the remnants of the P\{EP\} transposon present in these mutants (see text, Fig. 1 and Suppl. Fig. 1 for detailed explanation). $\beta$-Tubulin is a loading control.

the cell (Marygold et al., 2005). It is thus generally accepted that the Minute syndrome reflects a reduced protein synthesis resulting from insufficient ribosome function (Morata, Ripoll, 1975; Marygold et al., 2005). Mutations in several Drosophila genes involved in ribosome biosynthesis do not have dominant effects but, when homozygous, cause the same defective traits elicited by the dominant Minute mutations. The phenotype produced by these mutations is commonly designated as Minute-like (see for example, Cui, DiMario, 2007).

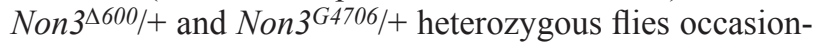
ally exhibit a limited reduction in bristle size but develop normally and are fertile. Thus, Non 3 mutations have only a minimal dominant effect. However, the combination of the Non $3^{G 4706}$ allele with any other weaker allele results in a clear Minute-like phenotype: prolonged development, poor viability and fertility, and abnormally short and thin bristles (Table, Fig. 2) (some flies had crumpled wings). To verify that all Non 3 phenotypes were due to a decrease in the Non3 protein level, we performed rescue experiments using a transgene that carries a full genomic copy of Non3 with its adjacent regulatory regions (see Fig. 1 and Suppl. Fig. 2). Mutant Non3 flies carrying one copy of this rescue construct ( $P[$ rescue $]$ ) showed normal viability and bristle length, and restored fertility (Fig. 2 and data not shown). Taken together, these findings indicate that Non 3 mutations behave like Minute-like mutations (Cui, DiMario, 2007). The finding that mutants in Non3 exhibit a Minute-like phenotype is not surprising. The $S$. cerevisiae Rpf2 protein is one of the many factors necessary for the assembly of the pre-60S subunits (Beidka et al., 2018) and it is likely that its Drosophila homologue Non3 participates in the same processes.

\section{Non3 hypomorphic mutations} reduce the Non 3 protein level

To further characterize the Non 3 mutant alleles, we raised a polyclonal anti-Non3 antibody in mice (see Materials and Methods for details). This antibody recognizes a band of the expected molecular weight $(\sim 37 \mathrm{kDa})$ in Western blots from $\mathrm{S} 2$ cell protein extracts; this band is substantially reduced in the extracts from Non 3 RNAi cells, confirming the specificity of the antibody (Fig. 3, $a, b$ ). It was suggested earlier that the short-spindle phenotype observed in Non 3 RNAi S2 cells is caused by limited translation of tubulin and/or other spindle components (Moutinho-Pereira et al., 2013). Our finding that Non3 RNAi-treated cells exhibit a normal tubulin level (see Fig. $3, b$ ) indicates that this phenotype is not caused by limited tubulin availability.

We next analyzed the levels of the Non3 protein in larval brains and salivary glands from the different Non $3 \mathrm{mu}-$ tants (see Fig. 3, c, d). In larval brain protein extracts from Non $3^{G 4706}$ homozygotes, the Non3 protein is drastically reduced, supporting the view that Non3 $3^{G 4706}$ is the strongest among the Non 3 hypomorphic mutations. Two copies of the rescue construct $(2 \times P[$ rescue $])$ restored the Non3 protein level in both Non3 $3^{G 406 / N o n} 3^{G 4706}$ and Non $3^{\Delta 600 / N o n 3^{\Delta 600}}$ mutants, approximately up to the level of Non $3^{\text {ex }}$ homozygous brains (see Fig. 3,c). We also found that Non3 is substantially reduced in salivary glands from Non $3^{197}$, Non $3^{310}$ and Non $3^{259}$ homozygotes. In addition to a reduction of the wild-type Non3 protein, the salivary glands of these mutants displayed immunoreactive proteins of $\sim 39-40 \mathrm{kDa}$ (see Fig. 3, $d$ ). Because the $N o n 3^{197}$, Non $3^{310}$ and Non $3^{259}$ mutations are carrying remnants of $P$-element ends, we believe that the aberrant Non3 proteins 


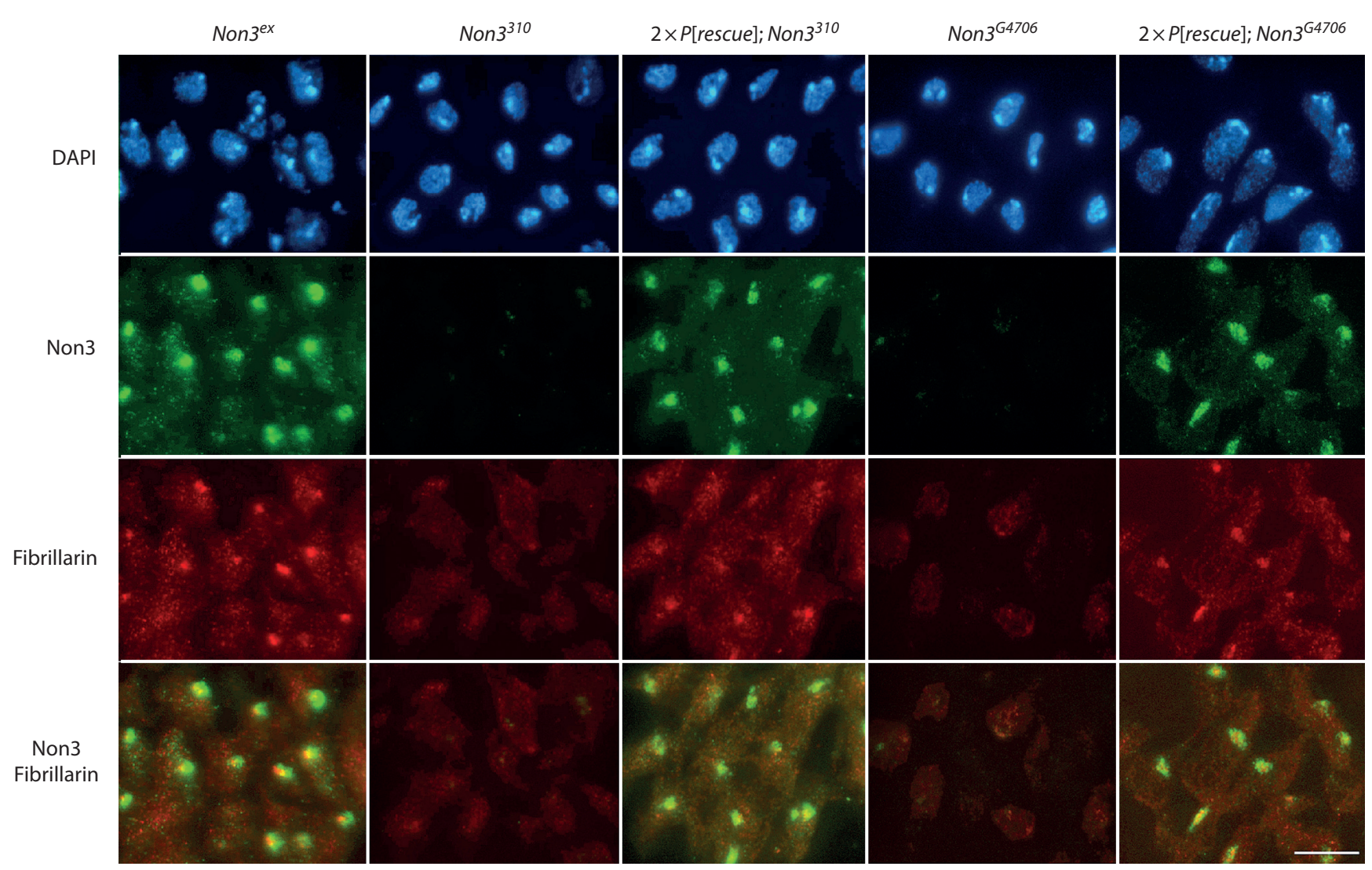

Fig. 4. Non3 localizes to the nucleoli of larval brain cells

In wild-type (Non3 ${ }^{e x}$ ) brain cells, Non3 largely co-localizes with the nucleolus marker Fibrillarin. Notably, brain cells from Non3 ${ }^{G 4706}$ and Non3 310 homozygous larvae not only show a strong decrease of Non3 signals but also of Fibrillarin signals. Scale bar is $10 \mu \mathrm{m}$.

are transcribed starting from ATG codons located within these P-element fragments (see Fig. 3, d; Suppl. Fig. 1).

\section{Nucleolar Non3 protein is required for proper Fibrillarin localization}

It has been previously shown that $\mathrm{S} 2$ cells transiently transfected with a plasmid encoding a GFP-Non3 fusion protein show a specific localization of the protein in the nucleolus (Moutinho-Pereira et al., 2013). We tried to confirm this Non3 localization by immunostaining $\mathrm{S} 2$ cells with our antibody, but were unable to see a clear signal. However, we successfully immunostained the nucleoli of larval brain cells (Fig. 4), possibly because nervous ganglia are one of the tissues with the highest level of Non3 expression (Gramates et al., 2017). In wild-type brain cells, Fibrillarin, the main component of the active nucleolus (Neumüller et al., 2013), co-localizes with Non3 in the nucleolus. In brain cells of homozygous Non $3^{G 4706}$ and Non $3^{310}$ mutants, we observed a drastic reduction of both Non3 and Fibrillarin in the nucleolus, suggesting that Non3 is required for Fibrillarin localization in nucleoli. The presence of the Non 3 rescue transgenes $(2 \times P[$ rescue $])$ restored the normal nucleolar signals of both proteins (see Fig. 4).

These results indicate that Non3 is a nucleolar protein that is required for proper Fibrillarin localization in the nucleolus. Fibrillarin is a major nucleolar protein with methyltransferase activity, playing roles in rRNA biogenesis and function (Rodriguez-Corona et al., 2015). Loss of nucleolar proteins such as Nopp140, Nop56, and Nop5 leads to mislocaliza- tion of Fibrillarin, compromises several nucleolar functions (Pederson, 1998; Olson, 2004), and causes developmental abnormalities (Cui, DiMario, 2007). The role of Non3 in Fibrillarin recruitment to the nucleolus is currently unknown and will be addressed in future studies.

\section{Conclusions}

We have generated several mutant alleles of the Non 3 gene and shown that viable combinations of these alleles exhibit a Minute-like phenotype, suggesting a role of Non3 in ribosome biogenesis. We have also shown that the Non3 protein localizes to the nucleolus and, most importantly, it is required for Fibrillarin recruitment to this organelle. Fibrillarin is a multifunctional protein that mediates methylation of several RNA species and plays roles in tumorigenesis and stem cell differentiation (Rodriguez-Corona et al., 2015; van Nues, Watkins, 2017). We believe that the Non3-related tools generated in our study will be instrumental to define the role of Non3 in RNA metabolism and to elucidate how it affects mitotic spindle formation. These tools will also help to investigate the mechanisms and biological significance of the interaction between Non3 and Fibrillarin.

\section{References}

Biedka S., Micic J., Wilson D., Brown H., Diorio-Toth L., Woolford J.L., Jr. Hierarchical recruitment of ribosomal proteins and assembly factors remodels nucleolar pre-60S ribosomes. J. Cell Biol. 2018;217(7):2503-2518. DOI 10.1083/jcb.201711037. 
Bischof J., Maeda R.K., Hediger M., Karch F., Basler K. An optimized transgenesis system for Drosophila using germ-line-specific $\varphi \mathrm{C} 31$ integrases. Proc. Natl. Acad. Sci. USA. 2007;104(9):3312-3317. DOI 10.1073/pnas.0611511104.

Bonaccorsi S., Giansanti M.G., Gatti M. Spindle assembly in Drosophila neuroblasts and ganglion mother cells. Nat. Cell Biol. 2000; 2(1):54-56. DOI 10.1038/71378.

Chalkley G.E., Verrijzer C.P. Immuno-depletion and purification strategies to study chromatin-remodeling factors in vitro. Methods Enzymol. 2004;377:421-442. DOI 10.1016/S0076-6879(03)77028-1.

Cui Z., DiMario P.J. RNAi knockdown of Nopp140 induces Minutelike phenotypes in Drosophila. Mol. Biol. Cell. 2007;18(6):21792191. DOI 10.1091/mbc.e07-01-0074.

Draptchinskaia N., Gustavsson P., Andersson B., Pettersson M., Willig T.N., Dianzani I., Ball S., Tchernia G., Klar J., Matsson H., Tentler D., Mohandas N., Carlsson B., Dahl N. The gene encoding ribosomal protein S19 is mutated in Diamond-Blackfan anaemia. Nat. Genet. 1999;21(2):169-175. DOI 10.1038/5951.

Farley-Barnes K.I., McCann K.L., Ogawa L.M., Merkel J., Surovtseva Y.V., Baserga S.J. Diverse regulators of human ribosome biogenesis discovered by changes in nucleolar number. Cell Rep. 2018; 22(7):1923-1934. DOI 10.1016/j.celrep.2018.01.056.

Fisher E.M.C., Beer-Romero P., Brown L.G., Ridley A., McNeil J.A., Lawrence J.B., Willard H.F., Bieber F.R., Page D.C. Homologous ribosomal protein genes on the human $\mathrm{X}$ and $\mathrm{Y}$ chromosomes: escape from $\mathrm{X}$ inactivation and possible implications for Turner syndrome. Cell. 1990;63(6):1205-1218.

Genuth N.R., Barna M. The discovery of ribosome heterogeneity and its implications for gene regulation and organismal life. Mol. Cell. 2018;71(3):364-374. DOI 10.1016/j.molcel.2018.07.018.

Goudarzi K.M., Lindström M.S. Role of ribosomal protein mutations in tumor development. Int. J. Oncol. 2016;48(4):1313-1324. DOI 10.3892/ijo.2016.3387.

Gramates L.S., Marygold S.J., Santos G.D., Urbano J.M., Antonazzo G., Matthews B.B., Rey A.J., Tabone C.J., Crosby M.A., Emmert D.B., Falls K., Goodman J.L., Hu Y., Ponting L., Schroeder A.J., Strelets V.B., Thurmond J., Zhou P., the FlyBase Consortium. FlyBase at 25: looking to the future. Nucleic Acids Res. 2017;45(D1):D663D671. DOI 10.1093/nar/gkw1016.

Gupta V., Warner J.R. Ribosome-omics of the human ribosome. RNA. 2014;20(7):1004-1013. DOI 10.1261/rna.043653.113.

Henras A.K., Plisson-Chastang C., O’Donohue M.F., Chakraborty A., Gleizes P.E. An overview of pre-ribosomal RNA processing in eukaryotes. Wiley Interdiscip. Rev. RNA. 2015;6(2):225-242. DOI 10.1002/wrna.1269.

Hoskins R.A., Carlson J.W., Wan K.H., Park S., Mendez I., Galle S.E., Booth B.W., Pfeiffer B.D., George R.A., Svirskas R., Krzywinski M., Schein J., Accardo M.C., Damia E., Messina G., Méndez-Lago M., de Pablos B., Demakova O.V., Andreyeva E.N., Boldyreva L.V., Marra M., Carvalho A.B., Dimitri P., Villasante A., Zhimulev I.F., Rubin G.M., Karpen G.H., Celniker S.E. The Release 6 reference sequence of the Drosophila melanogaster genome. Genome Res. 2015;25(3):445-458. DOI 10.1101/gr.185579.114.

Huang W., Massouras A., Inoue Y., Peiffer J., Ràmia M., Tarone A.M., Turlapati L., Zichner T., Zhu D., Lyman R.F., Magwire M.M., Blankenburg K., Carbone M.A., Chang K., Ellis L.L., Fernandez S., Han Y., Highnam G., Hjelmen C.E., Jack J.R., Javaid M., Jayaseelan J., Kalra D., Lee S., Lewis L., Munidasa M., Ongeri F., Patel S., Perales L., Perez A., Pu L., Rollmann S.M., Ruth R., Saada N., Warner C., Williams A., Wu Y.Q., Yamamoto A., Zhang Y., Zhu Y., Anholt R.R., Korbel J.O., Mittelman D., Muzny D.M., Gibbs R.A., Barbadilla A., Johnston J.S., Stone E.A., Richards S., Deplancke B., Mackay T.F.C. Natural variation in genome architecture among 205 Drosophila melanogaster Genetic Reference Panel lines. Genome Res. 2014;24(7):1193-1208. DOI 10.1101/gr.171546. 113.

Kearse M.G., Chen A.S., Ware V.C. Expression of ribosomal protein L22e family members in Drosophila melanogaster: rpL22-like is differentially expressed and alternatively spliced. Nucleic Acids Res. 2011;39(7):2701-2716. DOI 10.1093/nar/gkq1218.

Kongsuwan K., Yu Q., Vincent A., Frisardi M.C., Rosbash M., Lengyel J.A., Merriam J. A Drosophila Minute gene encodes a ribosomal protein. Nature. 1985;317(6037):555-558.

Kressler D., Hurt E., Baßler J. A puzzle of life: crafting ribosomal subunits. Trends Biochem. Sci. 2017;42(8):640-654. DOI 10.1016/j. tibs.2017.05.005.

Lopes A.M., Miguel R.N., Sargent C.A., Ellis P.J., Amorim A., Affara N.A. The human RPS4 paralogue on Yq11.223 encodes a structurally conserved ribosomal protein and is preferentially expressed during spermatogenesis. BMC Mol. Biol. 2010;11:33. DOI 10.1186/1471-2199-11-33

Mackay T.F., Richards S., Stone E.A., Barbadilla A., Ayroles J.F., Zhu D., Casillas S., Han Y., Magwire M.M., Cridland J.M., Richardson M.F., Anholt R.R., Barrón M., Bess C., Blankenburg K.P., Carbone M.A., Castellano D., Chaboub L., Duncan L., Harris Z., Javaid M., Jayaseelan J.C., Jhangiani S.N., Jordan K.W., Lara F., Lawrence F., Lee S.L., Librado P., Linheiro R.S., Lyman R.F., Mackey A.J., Munidasa M., Muzny D.M., Nazareth L., Newsham I., Perales L., Pu L.L., Qu C., Ràmia M., Reid J.G., Rollmann S.M., Rozas J., Saada N., Turlapati L., Worley K.C., Wu Y.Q., Yamamoto A., Zhu Y., Bergman C.M., Thornton K.R., Mittelman D., Gibbs R.A. The Drosophila melanogaster Genetic Reference Panel. Nature. 2012;482(7384):173-178. DOI 10.1038/nature10811.

Markstein M., Pitsouli C., Villalta C., Celniker S.E., Perrimon N. Exploiting position effects and the gypsy retrovirus insulator to engineer precisely expressed transgenes. Nat. Genet. 2008;40(4):476483. DOI $10.1038 / \mathrm{ng} .101$

Marygold S.J., Coelho C.M.A., Leevers S.J. Genetic analysis of RpL38 and RpL5, two Minute genes located in the centric heterochromatin of chromosome 2 of Drosophila melanogaster. Genetics. 2005;169(2):683-695. DOI 10.1534/genetics.104.034124.

Marygold S.J., Roote J., Reuter G., Lambertsson A., Ashburner M., Millburn G.H., Harrison P.M., Yu Z., Kenmochi N., Kaufman T.C., Leevers S.J., Cook K.R. The ribosomal protein genes and Minute loci of Drosophila melanogaster. Genome Biol. 2007;8(10):R216. DOI 10.1186/gb-2007-8-10-r216.

Mills E.W., Green R. Ribosomopathies: there's strength in numbers. Science. 2017;358(6363):eaan2755. DOI 10.1126/science.an2755.

Morata G., Ripoll P. Minutes: mutants of Drosophila autonomously affecting cell division rate. Dev. Biol. 1975;42(2):211-221.

Moutinho-Pereira S., Stuurman N., Afonso O., Hornsveld M., Aguiar P., Goshima G., Vale R.D., Maiato H. Genes involved in centrosomeindependent mitotic spindle assembly in Drosophila S2 cells. Proc. Natl. Acad. Sci. USA. 2013;110(49):19808-19813. DOI 10.1073/ pnas. 1320013110.

Narla A., Ebert B.L. Ribosomopathies: human disorders of ribosome dysfunction. Blood. 2010;115(16):3196-3205. DOI 10.1182/ blood-2009-10-178129.

Neumüller R.A., Gross T., Samsonova A.A., Vinayagam A., Buckner M., Founk K., Hu Y., Sharifpoor S., Rosebrock A.P., Andrews B., Winston F., Perrimon N. Conserved regulators of nucleolar size revealed by global phenotypic analyses. Sci. Signal. 2013;6(289):ra70. DOI 10.1126/scisignal.2004145.

Núñez Villacís L., Wong M.S., Ferguson L.L., Hein N., George A.J., Hannan K.M. New roles for the nucleolus in health and disease. BioEssays. 2018;40(5):e1700233. DOI 10.1002/bies.201700233.

O'Brochta D.A., Gomez S.P., Handler A.M. P element excision in Drosophila melanogaster and related drosophilids. Mol. Gen. Genet. 1991;225(3):387-394.

Ogienko A.A., Yarinich L.A., Fedorova E.V., Lebedev M.O., Andreyeva E.N., Pindyurin A.V., Baricheva E.M. New slbo-Gal4 driver lines for the analysis of border cell migration during Drosophila oogenesis. Chromosoma. 2018;127(4):475-487. DOI 10.1007/ s00412-018-0676-7.

Olson M.O.J. Sensing cellular stress: another new function for the nucleolus? Sci. STKE. 2004;2004(224):pe10. DOI 10.1126/stke. 2242004 pe10. 
Pederson T. The plurifunctional nucleolus. Nucleic Acids Res. 1998; 26(17):3871-3876

Robertson H.M., Preston C.R., Phillis R.W., Johnson-Schlitz D.M., Benz W.K., Engels W.R. A stable genomic source of $P$ element transposase in Drosophila melanogaster. Genetics. 1988;118(3):461-470.

Rodriguez-Corona U., Sobol M., Rodriguez-Zapata L.C., Hozak P., Castano E. Fibrillarin from Archaea to human. Biol. Cell. 2015; 107(6):159-174. DOI 10.1111/boc.201400077.

Shi Z., Barna M. Translating the genome in time and space: specialized ribosomes, RNA regulons, and RNA-binding proteins. Annu. Rev. Cell Dev. Biol. 2015;31:31-54. DOI 10.1146/annurevcellbio-100814-125346.

Somma M.P., Ceprani F., Bucciarelli E., Naim V., De Arcangelis V., Piergentili R., Palena A., Ciapponi L., Giansanti M.G., Pellacani C., Petrucci R., Cenci G., Vernì F., Fasulo B., Goldberg M.L., Di Cunto F., Gatti M. Identification of Drosophila mitotic genes by combining co-expression analysis and RNA interference. PLoS Genet. 2008;4(7):e1000126. DOI 10.1371/journal.pgen.1000126.

Somma M.P., Fasulo B., Cenci G., Cundari E., Gatti M. Molecular dissection of cytokinesis by RNA interference in Drosophila cultured cells. Mol. Biol. Cell. 2002;13(7):2448-2460. DOI 10.1091/mbc.0112-0589.

Stage D.E., Eickbush T.H. Sequence variation within the rRNA gene loci of 12 Drosophila species. Genome Res. 2007;17(12):18881897. DOI 10.1101/gr.6376807.

Strunov A., Boldyreva L.V., Pavlova G.A., Pindyurin A.V., Gatti M., Kiseleva E. A simple and effective method for ultrastructural analysis of mitosis in Drosophila S2 cells. MethodsX. 2016;3:551-559. DOI 10.1016/j.mex.2016.10.003.
Tavares A.A.M., Glover D.M., Sunkel C.E. The conserved mitotic kinase polo is regulated by phosphorylation and has preferred microtubule-associated substrates in Drosophila embryo extracts. EMBO J. 1996;15(18):4873-4883.

Tutuncuoglu B., Jakovljevic J., Wu S., Gao N., Woolford J.L., Jr. The $\mathrm{N}$-terminal extension of yeast ribosomal protein $\mathrm{L} 8$ is involved in two major remodeling events during late nuclear stages of $60 \mathrm{~S}$ ribosomal subunit assembly. RNA. 2016;22(9):1386-1399. DOI 10.1261/rna.055798.115.

van Nues R.W., Watkins N.J. Unusual $\mathrm{C}^{\prime} / \mathrm{D}^{\prime}$ motifs enable box $\mathrm{C} / \mathrm{D}$ snoRNPs to modify multiple sites in the same rRNA target region. Nucleic Acids Res. 2017;45(4):2016-2028.

Wehner K.A., Baserga S.J. The $\sigma^{70}$-like motif: a eukaryotic RNA binding domain unique to a superfamily of proteins required for ribosome biogenesis. Mol. Cell. 2002;9(2):329-339. DOI 10.1016/ S1097-2765(02)00438-0.

Xue S., Barna M. Specialized ribosomes: a new frontier in gene regulation and organismal biology. Nat. Rev. Mol. Cell Biol. 2012;13(6): 355-369. DOI 10.1038/nrm3359.

Yang X., Mao F., Lv X., Zhang Z., Fu L., Lu Y., Wu W., Zhou Z., Zhang L., Zhao Y. Drosophila Vps36 regulates Smo trafficking in Hedgehog signaling. J. Cell Sci. 2013;126(Pt.18):4230-4238. DOI $10.1242 /$ jcs. 128603 .

Zhang J., Harnpicharnchai P., Jakovljevic J., Tang L., Guo Y., Oeffinger M., Rout M.P., Hiley S.L., Hughes T., Woolford J.L., Jr. Assembly factors Rpf2 and Rrs1 recruit 5S rRNA and ribosomal proteins rpL5 and rpL11 into nascent ribosomes. Genes Dev. 2007;21(20):25802592. DOI 10.1101/gad.1569307.

ORCID ID

E.N. Andreyeva orcid.org/0000-0001-6997-0492

A.A. Ogienko orcid.org/0000-0002-0896-1899

A.A. Yushkova orcid.org/0000-0002-9037-6866

J.V. Popova orcid.org/0000-0001-8800-8645

G.A. Pavlova orcid.org/0000-0001-7361-5039

A.V. Ivankin orcid.org/0000-0003-3309-6363

M. Gatti orcid.org/0000-0003-3777-300X

A.V. Pindyurin orcid.org/0000-0001-6959-0641

Acknowledgements. We thank E.V. Fedorova for technical assistance with generation of Non3 mutants, G. Reuter for valuable discussion, H. Saumweber for anti- $\beta$-Tubulin antibody, and S.A. Demakov for providing the fly line carrying the attP40 landing site. This work was supported by a grant from the Russian Foundation for Basic Research (18-34-00699), by a grant from the Ministry of Education and Science of the Russian Federation (14.Z50.31.0005) for raising antibodies specific to Non3, and by a project of the Fundamental Scientific Research Program of the Siberian Branch of the Russian Academy of Sciences (0310-2019-0005) for generation of mutant Non3 alleles. The microscopy and DNA sequencing were performed using resources provided by the Molecular and Cellular Biology core facility of the Institute of Molecular and Cellular Biology of the Siberian Branch of the Russian Academy of Sciences. Antibodies were raised at the Center for Genetic Resources of Laboratory Animals, Institute of Cytology and Genetics, Siberian Branch of the Russian Academy of Sciences (RFMEFI61914X0005 and RFMEFI61914X0010).

Conflict of interest. The authors declare no conflict of interest.

Received December 6, 2018. Revised December 18, 2018. Accepted January 10, 2019 